\title{
Adaptive Transformations of News Text in the Media (Through Examples of Turkish, Russian and English Articles)
}

\section{Transformaciones adaptativas del texto de las noticias en los medios (a través de ejemplos de artículos en turco, ruso e inglés)}

Yilmaz Elvira Rafilovna

Kazan Federal University, Russia

ORCID: https://orcid.org/0000-0002-5649-6995

Khabibullina Elmira Kamilevna

Kazan Federal University, Russia

ORCID: https://orcid.org/0000-0002-3602-5686

Alikberova Alfiya Rafisovna

Kazan Federal University, Russia

ORCID: https://orcid.org/0000-0002-5094-3010

Received 09-08-20 Revised 10-10-20

Accepted 20-12-21 On line 02-16-21

* Correspondence

Email: el-vira-hadieva@yandex.ru
Citation:

Yilmaz Elvira Rafilovna, Khabibullina Elmira Kamilevna, Alikberova Alfiya Rafisovna. (2021). Adaptive Transformations of News Text in the Media (Through Examples of Turkish, Russian and English Articles). Propósitos y Representaciones, 9(SPE2), e998. doi: http://dx.doi.org/10.20511/pyr2021.v9nSPE2.998 


\section{Summary}

Informational texts always contain one or more forms of adaptation. The source material is changed according to the standards of the target culture. Adaptation elements can be easily detected by comparing texts in different languages used to reflect a particular news event. The research material of our article is news reports published on the information platforms $\mathrm{BBC}$ Turkçe, BBC Russian and BBC World on February-March 2020. Although there are several definitions of the term «adaptation», we adhere to the opinion of scientists, who disclose it in a broad sense. In this approach, the term «adaptation» refers to methods for adapting the original text (as a fragment for displaying objective and social realities) to the socio-cultural conditions of the implicit audience. The message addresser is a participant in this communication process, therefore he should determine the readiness of the implicit reader to accept/ understand/ interpret information. News adapted version is created basing on the perception capabilities. In the comparison of information texts, we also referred to the term «information cores», which means a single information unit of the incident, disclosed within the framework of the main topic.

Keywords: adaptation, mass media, information, socio-cultural adaptation, objectivity, social reality.

\section{Resumen}

Los textos informativos siempre contienen una o más formas de adaptación. El material de origen se cambia de acuerdo con los estándares de la cultura de destino. Los elementos de adaptación se pueden detectar fácilmente comparando textos en diferentes idiomas utilizados para reflejar un evento de noticias en particular. El material de investigación de nuestro artículo son informes de noticias publicados en las plataformas de información BBC Turkçe, BBC Russian y BBC World en febrero-marzo de 2020. Aunque existen varias definiciones del término «adaptación», nos adherimos a la opinión de los científicos, que revelan en un sentido amplio. En este enfoque, el término «adaptación» se refiere a métodos para adaptar el texto original (como un fragmento para mostrar realidades objetivas y sociales) a las condiciones socioculturales de la audiencia implícita. El destinatario del mensaje es un participante en este proceso de comunicación, por lo tanto, debe determinar la disposición del lector implícito para aceptar / comprender / interpretar información. Se crea una versión adaptada a las noticias en base a las capacidades de percepción. En la comparación de textos de información, también nos referimos al término «núcleos de información», que significa una unidad de información única del incidente, divulgada en el marco del tema principal.

Palabras clave: adaptación, medios de comunicación, información, adaptación sociocultural, objetividad, realidad social.

\section{Introduction}

Information texts contain one or more forms of adaptation: the source material is always a subject to changes according to the standards of the target culture. Adaptation elements are easily detected by comparing news texts in different languages.

In our research we turned to comparison of breaking news published in BBC Turkçe, BBC Russian and BBC World.

Although there are several definitions of the term «adaptation», we adhere to the opinion of those scientists who reveal it in a broad sense. This transformation is adaptation of the original text, as a fragment of the display of objective and social reality, to the socio-cultural conditions of social reality (Timko, 1999). 
According to modern scientists, there are several types of adaptation: collocation adaptation, cultural adaptation, literary adaptation and ideological adaptation (Assaqaf, 2016), it is one of the most relevant techniques used for translating information texts. News agencies provide information to regional publications, which, in turn, makes an adapted translation. Based on this, an up-to-date news text appears.

Texts of the information genre differ from other genres of mass media in: 1) their conciseness; 2) their desire for the most accurate and rapid transmission of news content; 3) their expressed detachment from the implementation of any emotional, expressive component and the author's assessment. However, due to the changed conditions for the sale of news products (the emergence of the Internet, the activation of online portals, the reduction of transmission time, the emergence of opportunities for instant implementation of photo and video material, etc.), news agencies and publishing houses began to resort to expanding the functional and informational content of news-oriented texts. These processes have led to a marked transformation of the form of content presentation, characterized by the desire to adapt as much as possible to the implicit audience.

Comparing media texts that cover the same news content, from the point of view of adaptation, it is necessary to address the issue of defining the genre. In this issue, we adhere to the position of the Soviet school of genre studies, which classified the genres of journalism by a single criterion - functionality. Today, this approach is considered universal and is optimal from the point of view of comparative research that analyzes compressed forms of news articles on the example of mass media materials in different languages. Based on the purpose, the genres were divided into informational, analytical, and art journalism.

\section{Methods}

Our article is based on the use of a system of research methods, namely, the descriptive method, which includes techniques for selecting, processing and interpreting material; the computational and analytical method; the comparison method; the method of component analysis; the method of contextual and discursive analysis, the method of inductive analysis.

\section{Results and Discussion}

According to A. A. Tertychny, information genres include news reports designed to carry out a kind of constant monitoring of the most significant and interesting events in a particular sphere of reality (Tertychny, 2000). Any message, whether it is a literary work or a newspaper article, serves the communicative purposes of society. Information has always been a commodity provided by news agencies to publications, which in turn sell it to the masses. Like any product, the message can be changed, adapted to the intended audience, based on socio-cultural, ideological, and other considerations. In other words, any practical information sought on the way to an implicit audience is subject to pragmatic adaptation: in order to achieve communicative success, the message is partially transformed. There are changes such as replacing less relevant data with more relevant ones; adding explanations or additional interpretation of certain points; omitting information that is not relevant to the intended audience.

Although the same publication (for example, BBC) prints the same news report in different languages, we can't call this an example of translation. In studies of foreign scientists, pragmatic adaptation is defined as «translative interventions which result in a text not generally accepted as a translation, but nevertheless recognized as representing a source text» (Baker \& Saldanha, 2011).

When comparing the articles with the BBC «Saudi Arabia bars foreigners from holy sites» (Rannard, 2020), «Koronavirüs (Covid-19): Suudi Arabistan umre ziyaretlerini askıya aldı» (Koronavirüs (Covid-19)) and «Вспышка коронавируса: Мекку закрыли для паломников; в Италии уже больше 450 заболевших» (https://www.bbc.com), the first published article is in English. Accordingly, the Turkish and Russian texts were adapted on the basis of this information. 
The headings of all three articles analyzed are identical, except for the fact that the headline in Russian has additional information: the author included statistics on the situation in Italy. This is due to the fact that in the English edition of BBC, the situation regarding the state of Affairs in Italy is covered in another article. The publication, aimed at the Turkish audience, purposefully left in the title only a message about the Affairs in Saudi Arabia. This move is explained by the desire of the message addressee to adapt the title to the recipient, who is in the zone of influence of cultural factors and religious traditions. This form of transformation is called cultural (Assaqaf, 2016). It should be noted that although Turkey is a Muslim country, it is very different from other Muslim countries: it still has traditions that originate from the pre-Muslim era. At the same time, Turkey is a territory where religious and secular elements are miraculously combined (Khabibullina \& Zaynullin, 2017). The addressee of an information message must take into account all these influences. Information about the negative impact of the coronavirus on the religious journey of Muslims to Mecca is not equivalent to information about the state of Affairs in Italy. Therefore, the addressee working with the Turkish audience did not decide to leave only relevant and most important information for the implicit reader in the title.

In addition to socio-cultural and religious adaptations, idealogical adaptations are often found in information genre texts. If we take the example of the societies of modern Russia, America and Turkey, we can confidently say that the attractor in each of them is the cultural ideal to which the leading parties «strive» the country. By the term attractor we mean a system based on the mutual tension of its elements; in the middle of this system is an attractor - a kind of «magnet» that creates a connection between the elements. According to the works of A. L. Dmitrovsky, the attractor is «a more or less stable position in which the system is able to exist comfortably» (Dmitrovsky, 2014). Based on the works of the scientist, we can say that old is referred to as a «strange attractor»: it is attracting a situation that is out of sight of the observer and has a more complex «system of paths» that leads to unpredictability of the system behavior in it» (Dmitrovsky, 2014).

\section{Summary}

The recipient's assessment and conclusions are based on the addressee 's arguments (Yilmaz et al., 2016). When adapting the text, the addressee of the information message is assigned the task of covering the information event, based on the characteristics of the attractor in each specific region, region, country. When comparing the form of a news report (in this case, a note), we can determine the main idea that serves to strengthen the influence of the attractor. The table below shows all three articles, with notes of the same and different points. The main idea of the Russian version is focused on highlighting the extent of the virus spread («продолжает распространяться за пределами Китая», «вирус затронул 48 стран, подтверждено около 82 тыс. случаев заболевания», «в других странах вирус распространяется быстрее...», «число заболевших ... выросло более чем на треть» (Rannard, 2020)) and the speed of its spread in a specific area («затронул 48 стран, подтверждено около 82 тыс. случаев заболевания» (Rannard, 2020)), in this light, information about the negative effects of the coronavirus on the lives of pilgrims remains in the shadows. Based on this, we can conclude that the ideological adaptation of the text for the Russian reader is formed based on such attractors as fear and caution.

The English text is aimed at a multi-faith audience: there are a number of additions that reveal the concept of Umrah in more detail to the implicit reader, the meaning of the Holy cities, etc. These points meet the requirements of the genre, do not violate the General concept, and serve the main idea contained in the title of the publication.

The text in Turkish is aimed at the intended audience, which does not require additional explanation about the essence of the pilgrimage. The text contains an explanation that in some sense duplicates the idea already expressed («geçici olarak durdurulduğunu belirtti» $=$ «durumun geçici olduğu ve değerlendirmelerin...» (Koronavirüs (Covid-19)). Thus, the addressee focuses on the problem-namely, the uncertainty of time intervals in which pilgrims are not allowed access to the Shrine. Also in the text there is a link to the source of information and to the statement of 
officials («Suudi Arabistan Dışişleri Bakanlığı'na dayandırdığı açılamasında» (Koronavirüs (Covid-19))).

If you highlight the core content, the text of the English language edition their 5:1) ban on entry for pilgrims; 2) a ban on the entry of tourists; 3 ) the lack of information on the lifting of the ban in July, during the Hajj; 4) an explanation of the Holy cities; 5) clarification on the extent of Umrah. In the English text 6: 1) the ban on entry for pilgrims; 2) the ban on entry for tourists; 3) lack of information about the lifting of the ban in July, during the Hajj; 4) clarification of the reasons for the behavior of the government of Saudi Arabia; 5) explanation of temporary measures; 6) link to information sources and officials.

The Russian text stands out dramatically against this background, and here we found the following information cores: 1) the spread of the virus outside of China; 2) statistics on confirmed cases of infection and death; 3) a link to the source of information; 4) the situation in Italy; 5) the ban on entry for pilgrims to Saudi Arabia.

If we reflect the data on the chart, we will see the following result.

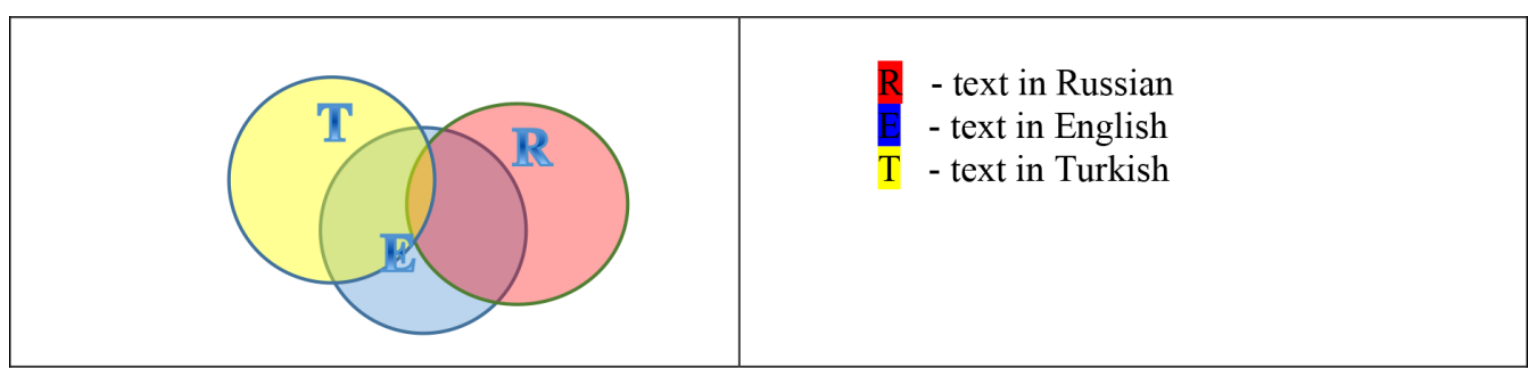

\section{Conclusions}

Thus, we can draw the following conclusions: the texts of information media are subject to adaptation, based on the goals of the addressee and the readiness of the implicit addressee. Each text is an attractum, the elements of which are information cores of the content. The attractor regulates the adaptation trajectory based on the needs of the addressee and the functionality of the text itself.

Studying of any foreign language as a means of communication should go in hand with learning the cultural aspects of the country and its people (Khabibullina \& Alfiya, 2015). First of all, language is in existence in the world of its speakers and learning of any language without considering this world, the country (geography, the population), culture, history, turns it into a passive language (Balakin et al., 2019).

\section{Acknowledgements}

The work is performed according to the Russian Government Program of Competitive Growth of Kazan Federal University.

\section{References}

Assaqaf, T.A.E. (2016). Adaptation as a Means of Translation. International Journal of Science and Research, 5(1), 783-785.

Baker, M., \& Saldanha, G. (2011). Routledge Encyclopedia of Translation Studies. New York: Routledge, $1364 \mathrm{p}$.

Balakin, D.A, Alikberova, A.R, \& Nazarova, S.A. (2019). Internet-memes in Chinese mediasphere as a reflection of modern reality. Journal of Sociology and Social Anthropology,10(4), 309-314.

Dmitrovsky, A.L. (2014). Genres of Journalism. Scientific notes of Oryol State University, 4(60), 149-158. 
Khabibullina, E., Alfiya, S.H. (2015). Yusupova Lexical Transformations in the Translations of the Modern Tatar Literature into the Turkish Language. Journal of Sustainable Development, ISSN 1913-9063 (Print) ISSN 1913-9071 (Online)

Khabibullina, E.K., Zaynullin, G.G. (2017). Transformation of phraseological units in the translation of fiction from the Tatar language into Turkish. Kazan Science, 10, 119-122.

Koronavirüs (Covid-19): Suudi Arabistan umre ziyaretlerini askiya ald. https://www.bbc.com/turkce/haberler-dunya-51639586 [03/01/20]

Outbreak of coronavirus: Mecca closed to pilgrims; there are already more than 450 cases in Italy. https://www.bbc.com/russian/news-51654179 [03/01/20]

Rannard, G. (2020). Saudi Arabia bars foreigners from holy sites. https://www.bbc.com/news/live/world-51655133 [03/01/20]

Tertychny, A.A. (2000). Genres of the periodical press: Textbook. Moscow: Aspect Press, 312 pp.

Timko, N.V. (1999). The cultural component of the linguistic-ethnic barrier. Scientific notes of ROSI. Series: Linguistics. Intercultural communication. Translation, 2, Kursk: Publishing house of ROSI, S. 220.

Yilmaz, E.R., Tarasova, F.Kh., \& Ashrapova, A.Kh. (2016). Speech Act of Approval as a Separate Component of a Positive Assessment Speech Act. Journal of Language and Literature, ISSN: 2078-0303, 7(2), 195-198.

Comparative table of texts №1

\begin{tabular}{|c|c|c|}
\hline $\begin{array}{l}\text { Saudi Arabia has stopped } \\
\text { foreigners from entering the } \\
\text { country for religious visits, } \\
\text { including to the two holiest } \\
\text { sites in Islam - Mecca and } \\
\text { Medina. Millions of people go } \\
\text { to the country throughout the } \\
\text { year for Umrah with a big surge } \\
\text { in visitors during the Hajj } \\
\text { pilgrimage. It's unclear if Hajj, } \\
\text { which is due to begin in late } \\
\text { July, will be affected. The } \\
\text { country has also barred visitors } \\
\text { from countries where the new } \\
\text { coronavirus has spread. Saudi } \\
\text { Arabia has no confirmed cases } \\
\text { of the disease. }\end{array}$ & 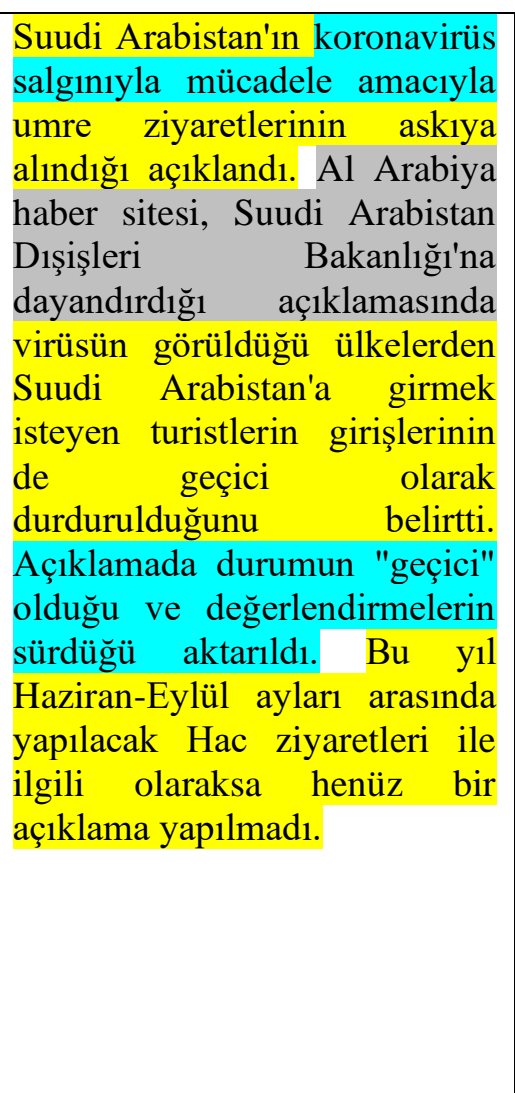 & 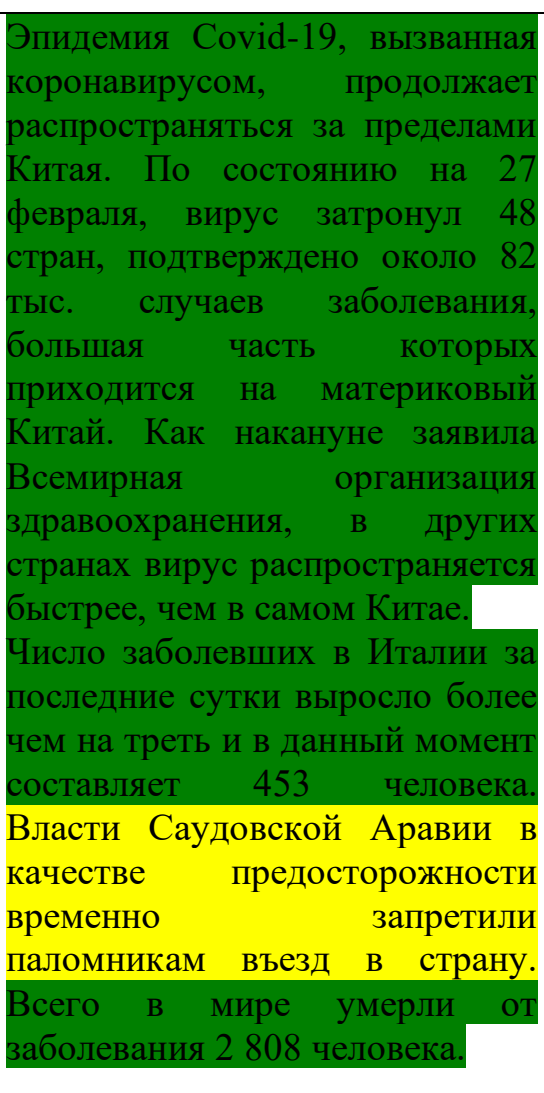 \\
\hline mentary informot & & \\
\hline
\end{tabular}

